\title{
Comparative evaluation of simultaneous administration of mifepristone and misoprostol; and misoprostol alone for induction of second trimester abortion
}

\author{
Ankita Jain ${ }^{1}$, Arpit Agarwal ${ }^{2 *}$
}

${ }^{1}$ Department of Obstetrics and Gynecology, ${ }^{2}$ Department of Cardiology, S.P.M.C., Bikaner, Rajasthan, India

Received: 24 April 2018

Accepted: 23 May 2018

\section{*Correspondence:}

Dr. Arpit Agarwal,

E-mail: anky3aug@gmail.com

Copyright: () the author(s), publisher and licensee Medip Academy. This is an open-access article distributed under the terms of the Creative Commons Attribution Non-Commercial License, which permits unrestricted non-commercial use, distribution, and reproduction in any medium, provided the original work is properly cited.

\begin{abstract}
Background: The present study was conducted with the aim to assess the safety and efficacy of misoprostol alone and misoprostol with simultaneous mifepristone for second trimester termination of pregnancy.

Methods: The study was conducted on 160 cases, divided in two groups of 80 cases each. In the study group $200 \mathrm{mg}$ mifepristone and $200 \mu \mathrm{gm}$ misoprostol given together on admission followed by miso every 3 hrs upto a maximum of 8 doses or until the abortion occurs, whichever occurs early. In the control group only miso was given in the same dose regime. If abortion did not occur within this duration it was considered failure of method. The results were analysed.

Results: The success rate in first regimen was $98 \%$. Mean induction abortion interval was significantly shorter in the study group, $8.62 \pm 1.96 \mathrm{~h}$ as compared to $14.5 \pm 3.01 \mathrm{~h}$ in the control group. The mean dose of the misoprostol required was significantly less in study group. The side effects like nausea, vomiting, fever, abdominal cramps, diarrhoea were observed more in control group (30\%) in comparison to study group (12.1\%).

Conclusions: Mifepristone with simultaneous misoprostol is better than misoprostol alone and there is no need to wait for $24 \mathrm{hr}$ after mifepristone for administration of misoprostol.
\end{abstract}

Keywords: Second trimester termination of pregnancy, Mifepristone, Misoprostol

\section{INTRODUCTION}

Induced abortions are major cause of maternal mortality. Large population who cannot afford, succumb to cheaper methods of abortion practices that eventually risk their lives. Today mortality rate due to abortions has reached upto $12 \%$ of maternal mortality rate.

In an effort to curb criminal abortions and maternal mortality government of India legalized abortion upto 20 weeks of pregnancy in year 1971. Second trimester abortion carries 20 times higher maternal mortality rate as compared to $1^{\text {st }}$ trimester. Mid trimester abortion usually carried out by induction rather than by $\mathrm{D} \& \mathrm{E}$, though in western world; D \& E dilatation and evacuation is still being preffered. But in India; nonsurgical methods like i.v oxytocin infusion, dinoprostone gel, intra amniotic infusion by hyperosmolar urea or hypertonic saline, extra amniotic infusion by ethacridine lactate etc singly or in combination are being used, accepting potential complications associated with each method.

But with the introduction of prostaglandin and analogues efficacy improved and complications reduced. Initially Misoprostol alone was used for medical abortion upto 49 days. It was first approved in France in 1988 followed by approval in UK in 1991. Either vaginally or orally it reaches peak level in 20-30 min and level remain in blood 
upto 3-4 hrs. But many side effects being reported like nausea, vomiting, diarrhea, fever with chills, headache, delirium, hyperpyrexia $>40^{\circ} \mathrm{C}$. A case has been reported where woman died of multiorgan failure due to overdose of misoprostol. Misoprostol is used in different regimen with induction abortion interval varying from $12 \mathrm{hrs}$ to as high as 33 hrs. ${ }^{1-8}$

Later on antiprogesterone drug mifepristone was tried with misoprostol. It typically acts on uterine wall; increases contraction, does cervical priming. Subsequently it was successfully used for later gestation abortions also (>49 days till 20 weeks) associated with lesser side effects than misoprostol and less time consuming.

In our hospital many a times women come for II $^{\text {nd }}$ trimester MTP with sterilization. They generally undergo MTP with sequential misoprostol and have to stay in hospital for $24-48 \mathrm{hrs}$ with occasional failures. They are parous women with small children at home, staying in the hospital is very inconvenient to them. The addition of mifepristone seems to be a logical option to decrease the induction abortion interval.

\section{METHODS}

This prospective observational study was conducted on selected 160 cases coming in Gyne OPD of SVBP hospital, LLRM Medical College Meerut for MTP with tubal ligation from August 2012 to September 2013. A detailed history of the case was obtained. Inclusion criteria were age $>18 \mathrm{yr}$, singleton pregnancy, gestational week: 12-20 weeks, legal indication for termination of pregnancy General and systemic examination of the cases was done. Criteria like gestation age $<12$ weeks and $>20$ weeks, ectopic pregnancy, anemia $<8$ gm, bleeding disorder, patients on long term steroids, patients on anticoagulants, chronic renal/ adrenal/ liver/ respiratory/ heart disease, any cerebrovascular disorder or any known allergy were excluded from the study. Cases were randomly divided in two groups of 80 each.

Study group (group A): received $200 \mathrm{mg}$ of mifepristone with misoprostol on admission followed by $200 \mu \mathrm{g}$ of misoprostol vaginally every $3 \mathrm{hrs}$ until the abortion occurred or up to a maximum of 8 doses.

Control group (group B): received misoprostol only in the same dose schedule.

The cases were closely monitored for side effects, total dose of misoprostol required, no of incomplete abortions warranting surgical evacuation. Induction abortion interval was noted. The process was considered failed if abortion did not occur even after 8 doses of misoprostol. If placenta was retained for more than $2 \mathrm{~h}$ surgical evacuation was done. In case of failure another method medical or surgical was tried. The data were analyzed by using appropriate statistical methods.

\section{RESULTS}

Majority of the cases in both the groups were between 21 and 30 years of age. The mean gravidity of the cases was $4.59 \pm 1.34$ years in the study group and $3.98 \pm 1.50$ in the control group. The mean gestational age was $16.04 \pm 2.57$ and $14.03 \pm 3.92$ weeks in the study and the control groups respectively (Table 1).

Table 1: Socio-demographical.

\begin{tabular}{|lll|}
\hline Factors & $\begin{array}{l}\text { Mifepristone+ } \\
\text { Misoprostol } \\
\text { (Group A) }\end{array}$ & $\begin{array}{l}\text { Misoprostol } \\
\text { only } \\
\text { (Group B) }\end{array}$ \\
\hline Age & & $26.02 \pm 4.7$ \\
\hline Mean in years & $26.3 \pm 3.08$ & 23 \\
\hline Minimum & 22 & 36 \\
\hline Maximum & 35 & \\
\hline Gravidity & & $3.98 \pm 1.5$ \\
\hline Mean & $4.59 \pm 1.34$ & 3 \\
\hline Minimum & 3 & 8 \\
\hline Maximum & 8 & \\
\hline Gestational age & & $14 \pm 3.9$ \\
\hline Mean in weeks & $16.04 \pm 2.5$ & 12 \\
\hline Minimum & 12 & 20 \\
\hline Maximum & 20 & \\
\hline
\end{tabular}

Table 2: Abortion induction interval (in hrs).

\begin{tabular}{|lll|}
\hline $\begin{array}{l}\text { Abortion induction } \\
\text { interval (hrs) }\end{array}$ & $\begin{array}{ll}\text { Group A } \\
(\mathbf{n}=78)\end{array}$ & $\begin{array}{l}\text { Group B } \\
(\mathbf{n}=74)\end{array}$ \\
\hline Mean & 8.61 & 14.55 \\
\hline SD & 1.94 & 3.09 \\
\hline
\end{tabular}

$\mathrm{P}$ value $=0.0001(\mathrm{HS})$

$90 \%$ of the cases aborted within 9 hours in the study group after the insertion of the first misoprostol tablet as against only $43 \%$ in the misoprostol alone group. All cases except two in the study group aborted within 15 hours as against only $79 \%$ in the control group. The mean induction abortion interval was $8.62 \pm 1.96$ hours as compared to $14.50 \pm 3.01 \mathrm{~h}$ in the control group (P <0.001) (Table 2).

Table 3: Comparison of doses of misoprostol.

\begin{tabular}{|lll|}
\hline Of doses of misoprostol & $\begin{array}{l}\text { Group A } \\
(\mathbf{n = 7 8})\end{array}$ & $\begin{array}{l}\text { Group B } \\
(\mathbf{n}=74)\end{array}$ \\
\hline Mean & 3.72 & 6.55 \\
\hline SD & 0.72 & 1.282 \\
\hline
\end{tabular}

P-value $=0.0001(\mathrm{HS})$

The mean dose of the misoprostol required was significantly less in the study group $3.76 \pm 291.64 \mu \mathrm{g}$ as compared to $6.75 \pm 320.20 \mu \mathrm{g}$ in the control group, respectively ( $\mathrm{P}<0.001)$ (Table 3$)$.

Success rate varied in both the groups. $2.5 \%$ ( 2 out of 80 ) cases of study group did not abort even after 8 doses of 
misoprostol. 7\% (6 out of 80) failure cases were reported in control group. The abortion was complete in $80 \%$ of the study group while $70 \%$ in the control group. Just 18 out of 80 cases in study group require further curettage where as in control group 34 out of 80 cases required curettage $(\mathrm{P}<0.001)$.

Table 4: Comparison of abortion induction interval (in hrs) in relation to gravida- parity and gestational age in weeks.

\begin{tabular}{|lll|}
\hline Parity & $\begin{array}{l}\text { Mifepristone+ } \\
\text { Misoprostol }\end{array}$ & Misoprostol \\
\hline $3-5$ & $9 \pm 1.84$ & $14.6 \pm 3.01$ \\
\hline $6-8$ & $7 \pm 1.94$ & $11 \pm 2.2$ \\
\hline Weeks & & \\
\hline $12-16$ & $8.4 \pm 1.8$ & $15 \pm 1.4$ \\
\hline $18-20$ & $7.2 \pm 1.8$ & $10 \pm 2.1$ \\
\hline
\end{tabular}

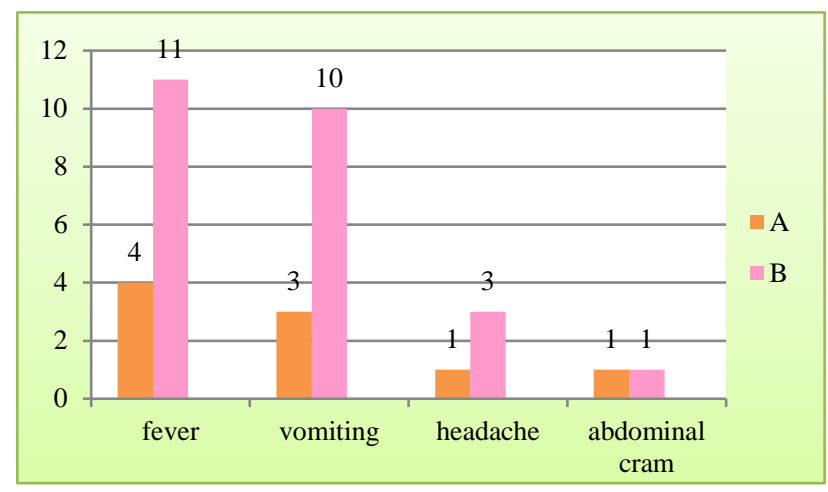

Figure 1: Comparison of side effects among the two groups.

The commonly observed side effects were nausea, vomiting, fever, abdominal cramps, diarrhea and were observed more in control group (approx 30\%) in comparison to study group (approx 12\%).

\section{DISCUSSION}

Second trimester abortions constitute $10-15 \%$ of all induced abortions worldwide but are responsible for twothirds of major abortion-related complications.

During the last decade, medical methods for second trimester induced abortion have been considerably improved and become safe and more accessible. Today, in most cases, safe and efficient medical abortion services can be offered or improved by minor changes in existing health care facilities.

The combination of mifepristone and misoprostol is now an established and highly effective method for second trimester abortion. Where mifepristone is not available or affordable, misoprostol alone has also been shown to be effective, although a higher total dose is needed and efficacy is lower than for the combined regimen.
Therefore, whenever possible, the combined regimen should be used. Efforts should be made to reduce unnecessary surgical evacuation of the uterus after expulsion of the fetus.

Combination of mifepristone with misoprostol is now widely used method for second trimester pregnancy termination. Priming of the uterus with mifepristone makes it more sensitive to prostaglandins. It binds with the progesterone receptors and antagonizes the actions of progesterone on prostaglandin synthesis and metabolism resulting in increase in production and decreased deactivation of prostaglandins. It also induces cervical softening thus, enhancing the efficacy of the prostaglandins as an abortifacient.

The time interval between the insertion of the first tablet of misoprostol and start of contraction was found to be significantly shorter in our study group as against the misoprostol alone group $(\mathrm{P}<0.001)$.

The time interval between the insertion of the first tablet and the start of the bleeding was also significantly shorter in the study group as compared to control group $(\mathrm{P}<0.001)$. The induction abortion interval was significantly shorter $8.62 \pm 1.96 \mathrm{~h}$ in the study group while it was $14.5 \pm 3.01 \mathrm{~h}$ in the misoprostol alone group $(\mathrm{P}<0.001)$.

Rodger et al in a double blind study using $600 \mathrm{mg}$ mifepristone $36 \mathrm{~h}$ prior to gemeprost found that the induction abortion interval was significantly reduced to $6.8 \mathrm{~h}$ as compared to $15.8 \mathrm{~h}$ in the placebo group but in that study patient has to stay or wait for more than one day for sequential misoprostol. ${ }^{9}$ In our study our aim was to reduce patient stay in hospital, so mifepristone was given simultaneously with misoprostol and it was found that abortion induction interval was very much reduced $(8$ hrs) and patient don't have to stay for long in hospital.

Netherland study it was found that time between first administration of misoprostol and abortion induction is significantly longer (time $11.3 \mathrm{hr}$ ) in comparison to combination of mifepristone and miso (mean time $9.3 \mathrm{hr}$ ) but no significant difference were found in frequency of side effects like nausea, vomiting etc. In Ashok et al 2004 and Gemzell Danielson 2008 study mifepristone was given 48 hours prior to misoprostol and abortion induction interval came out to be 9.4 hours. ${ }^{10,11}$

In Cunningum FG study mifepristone was given $48 \mathrm{hrs}$ prior to vaginal misoprostol. ${ }^{12,13}$

In RCT 2011 ngoc NT et al study mifepristone was given $36 \mathrm{hrs}$ prior to misoprostol and abortion induction interval was 10 hours In this present study we found that abortion interval was reduced very much $(8.6 \mathrm{hrs})$ in comparison to misoprostol only group (15 hrs). ${ }^{12,13}$ Also there was very much reduction in no of side effects in comparison to misoprostol only group (12\% vs $30 \%$ ). 
Table 5: Comparison of study group with previous different studies.

\begin{tabular}{|lllll|}
\hline Study & Dosage & $\begin{array}{l}\text { Abortion induction } \\
\text { interval }\end{array}$ & $\begin{array}{l}\text { Frequency of } \\
\text { S/E }\end{array}$ & $\begin{array}{l}\text { Efficacy } \\
\text { rate \% }\end{array}$ \\
\hline Rodger et al & $\begin{array}{l}\text { Mifepristone } 600 \mathrm{mg} 36 \mathrm{hrs} \\
\text { prior to gemeprost }\end{array}$ & 6.8 hours & $\begin{array}{l}\text { Similar to } \\
\text { placebo group }\end{array}$ \\
\hline Netherland study & $\begin{array}{l}\text { Mifepristone } 200 \mathrm{mg} 36 \mathrm{hrs} \\
\text { prior to misoprostol }\end{array}$ & 9.3 hours & $\begin{array}{l}\text { Similar to } \\
\text { placebo group }\end{array}$ \\
\hline $\begin{array}{l}\text { Ashok et al, Gemzell } \\
\text { Danielson }\end{array}$ & $\begin{array}{l}\text { Mifepristone } 48 \mathrm{hrs} \text { prior to } \\
\text { misoprostol }\end{array}$ & 9.4 hours & \\
\hline Cunningum FG et al & $\begin{array}{l}\text { Mifepristone } 200 \mathrm{mg} 48 \mathrm{hrs} \\
\text { prior to vaginal misoprostol }\end{array}$ & 8.4 hours & \\
\hline Ngoc NT et al ${ }^{14}$ & $\begin{array}{l}\text { Mifepristone } 36 \mathrm{hrs} \text { prior to } \\
\text { misoprostol }\end{array}$ & 10 hours & & \\
\hline Present study & $\begin{array}{l}\text { Mifepristone with misoprostol } \\
\text { without any gap }\end{array}$ & 8.6 hours & $\begin{array}{l}\text { Fewer side } \\
\text { effects (12\%) }\end{array}$ & 98 \\
\hline
\end{tabular}

The success rate was $98 \%$ in the present study. The mean dose of misoprostol required was significantly less when used in combination with mifepristone. The commonly observed side effects were nausea, vomiting, fever, abdominal cramp and diarrhea and were significantly less in study group as compared to control group.

\section{CONCLUSION}

Though conventionally in medical abortion misoprostol is given after mifepristone after a gap of 24-48 hrs, coadministration of mifepristone with misoprostol without any gap is highly cost effective method with a high success rate and shorter abortion induction interval. The availability of second trimester medical abortion as a day care procedure can minimize disruption to the lives of women and their families.

\section{Funding: No funding sources}

Conflict of interest: None declared

Ethical approval: The study was approved by the Institutional Ethics Committee

\section{REFERENCES}

1. Wong KS, Ngai CS, Yeo EL, Tang LC, Ho PC. A comparison of two regimen of intravaginal misoprostol for termination of second trimester pregnancy: a randomized trial. Hum Reprod. 2000;15(3):709-12.

2. Herbutya Y, Chanarchakul B, Punyavachira P. Vaginal misoprostol in the termination of second trimester pregnancy. J obstet Gynaecol Res. 2000;26:121-5.

3. Pongsatha S, Tongsong T. Second trimester pregnancy termination with $800 \mathrm{mcg}$ vaginal misoprostol. J Med Assoc thai. 2001;84:859-63.

4. Herbutya Y, Chanarchakul B, Punyavachira P. Second trimester: a comparison of 600 and $800 \mu \mathrm{g}$ of intravaginal misoprostol. J Obstet Gynaecol Res. 2001;27:125-8.
5. Gilbert A, Reid R. A randomized trial of oral versus vaginal administration of misoprostol for the purpose of mid trimester terminationof pregnancy. Aust $\mathrm{N} \mathrm{Z} \mathrm{J}$ obsetet Gynaecol. 2001;41:407-10.

6. Ramin KD, Ogburn PL, Danilenko DR, Ramsey PS. High dose oral misoprostol for mid trimester pregnancy interruption. J gynecol obstet invest. 2002;54:176-9.

7. Dickinoson JE, Evans SF. A comparison of oral misoprostol with vaginal misoprostol administration in second trimester pregnancy termination for fetal abnormality. Obstet Gynecol. 2003;102:1294-9.

8. Tang Os, Lau WNT, Chan CCW, Ho PC. A Prospective randomized comparison of sublingual and vaginal misoprostol in second trimester termination of pregnancy. Br J obstet Gyneacol. 2004;111(9):1001-5.

9. Premila WA, Templeton A. Nonsurgical mid trimester termination of pregnancy; a review of 500 consecutive cases. Br J Obstet Gyneacol. 1999;106:706-10.

10. Ashok PW, Penney GC, Flett GM, Templeton A. An effective regimen for early medical abortion : Report of 2000 consecutive cases. Hum Reprod. 1998;13(1O):2962-5.

11. Gemzell Danielsson K, Lalit Kumar S. Reproductive health matters. Am Coll Obstet Gynecol. 2008;16(31 supplement):162-72.

12. Cunningham FG, Leveno KJ, Bloom SL, Hauth JC, Rouse DJ, Spong CY. Williams Obstetrics, 23rd edition, McGraw-Hill publication; 2010: 232-233.

13. Cunningham FG, Leveno KJ, Bloom SL, Hauth JC, Rouse DJ, Spong CY. Williams Obstetrics, 22nd edition, McGraw-Hill publication; 2005: 246 -247.

14. Ngoc NT, Shochet T, Raghavan S, Blum J, Nga NT, Minh NT, et al. Mifepristone and misoprostol compared with misoprostol alone for second-trimester abortion: a randomized controlled trial. Obstet Gynecol. 2011;118(3):601-8.

Cite this article as: Jain A, Agarwal A. Comparative evaluation of simultaneous administration of mifepristone and misoprostol; and misoprostol alone for induction of second trimester abortion. Int J Reprod Contracept Obstet Gynecol 2018;7:2728-31. 